\title{
A Study of Shakespeare Contribution in Hindi Cinema
}

\author{
Asma Qureshi
}

\begin{abstract}
In India, Cinema not only a name of entertainment, but also educate to millions of people every day. Friday is celebrated by screening of new films. Indians happily participate in Cinema culture of the Country. Shakespearean tragedies have been a never ending source of inspiration for all filmmakers across the world. Many Hindi films based on Shakespeare novel like Shahid, Omkara, Goliyo ki raasleela Ramleela etc. William Shakespeare in India has been an exceptional and ground-breaking venture. The literary collection of Shakespeare is dynamic and an unlimited source of inspiration for countless people across the globe. When Shakespeare's writing is adapted in cinema, it sets it ablaze, and transfers the audience to a cinematic paradise. Indian adaptation of both Shakespearean tragedy and comedy can be comprehended as an Combination of 'videsi' and 'desi', a synthesis of East and West, and an Oriental and Occidental cultural exchange. Shakespeare's, "bisexual" mind, the complexity of his Narrative, music, story-telling, and creative sensibility categorizes him as an ace literary craftsman. This Research is an attempt to understand the contribution of Shakespeare novel in Hindi cinema. So that we can easily understand the main theme of the story. What writer wants to share with us. We can easily understand main theme of novel.
\end{abstract}

\section{Introduction}

Indian Hindi language film industry is also known as Hindi cinema which is situated or we can say mainly operated from Mumbai (MH) India. Hindi films conquer $43 \%$ of the net box office and movies based on Tamil, Telugu or in other regional language conquer remaining 57\%. The first Hindi movie was "Raja Harishchandra" produced by Dada sahib Phalke. The first movie with sound was "Alam Ara" made by Ardeshir Irani. The first color movie was "Kisan Kanya". The most famous author in English literature is Shakespeare. He wrote 38 plays, 154 sonnets, 2 epic poems. A Parsi theatre bought Shakespeare to Hindi cinema. The Parsi theatre develops between 1870 \& 1940 adapting Shakespeare to India. Parsi theatre dramatist recreated his emotions with trick and plot they draft it so well that main theme of the drama is not changed and people will easily understand and get entertained. The long History of Shakespeare in Hindi cinema is a powerful tool in the hand of directors who show Indian thinking in a global culture through a Shakespearean lens. It's been 450 years since he passed on but he is still remembered by the people. Just because of his works .His plays inspired several generation's filmmakers across the world through his different and innovative ideas. He is very general in nature. Every character is sharply separated and have universal appeal. His dialogue is based on actual conversation of people. In short we can say that his plays are reflection of life. So people are getting interest in that. In India Shakespeare is kept alive by Hindi Cinema, interpreting his work in various ways.

\section{Review of Literature}

It is easy to see Shakespeare as simply one of the legacies of British colonialism in India. But his popularity in Hindi cinema is not just the culmination of Thomas Macaulay's Minute on Indian Education (1835), in which the colonial official infamously declared that "a single shelf of a good
European library worth the whole native literature of India and Arabia". It also has a lot to do with profound resonances between Shakespeare's craft and Indian cultural forms that converge on one concept: masala.

Habib Faisal's Ishaqzaade (2012) loosely based on Romeo and Juliet, features a memorable item number, "Jhalla Walla". Who can forget punning lines like "Aashiqon Main Jis Ka Title Titanic" and "Jisko Mohabbat Ka Teacher Kehte Rahe/ Woh Fatichar ek lesson Mein Fail Ho Gaya"? The overwhelming experience of "Jhalla Walla" is of words straying across borders and romancing strangers from forbidden households. The song's climactic declaration of affection passes through four languages - from Hindi to English ("Mera Hero") to Urdu ("Mera Aashiq") to Persian/Arabic ("Mera Majnu") and finally to a term common to Hindi and Urdu ("Mera Saiyaan"). These puns and swerves, refusing to stay put within the boundaries of any one pure tongue, create a soundscape in which audience members can subliminally celebrate the resistance of desire, like language, to custom and convention. Just as words from different languages can mate in the same sentence, so can a Hindu Romeo and a Muslim Juliet fall in love. And this is where Jhalla Walla's lyrics are most Shakespearean. If Romeo and Juliet is about forbidden love, it's not just love between a man and a woman — it's also love between languages that are supposedly separate. In the opening lines of the play, Shakespeare puns on "coal" (a word of German origin), "collier" (French), "choler" (Latin), and "collar" (Italian) - creating the perfect subliminal backdrop for his story of love between different communities. Romeo and Juliet ask us to embrace a politics of masala.

\section{Aims of the study}

The Aim of this study to determine systematically reviewing the literature of Shakespeare contribution in Indian cinema. 


\section{International Journal of Science and Research (IJSR) \\ ISSN (Online): 2319-7064}

Index Copernicus Value (2016): 79.57 | Impact Factor (2015): 6.391

Conceptual framework of Shakespeare contribution in Hindi cinema

\begin{tabular}{|l|l|l|l|}
\hline Shakespeare speaks many tongues & Director & Based on which play? \\
\hline Language & Film & Ajoy Kar & $\begin{array}{l}\text { Based on Tarashankar Bandhopadhyay's novel. However, there is a section } \\
\text { where the leads perform Othello. }\end{array}$ \\
\hline Bengali & Saptapadi (1961) & Manu Sen & The Comedy Of Errors \\
\cline { 2 - 4 } & Bhrantibilas (1963) & Ranjan Ghosh & Othello, Macbeth and Hamlet. \\
\cline { 2 - 4 } & Hrid Majharey (2014) & Srijit Mukherjee & Julius Caesar and Anthony and Cleopatra \\
\cline { 2 - 4 } & Zulfiqar & Aparna Sen & Romeo and Juliet \\
\cline { 2 - 4 } & Arshinagar (2015) & Anjan Dutt & Hamlet \\
\cline { 2 - 4 } & Hemanta & Vishal Bhardwaj & Macbeth \\
\hline \multirow{4}{*}{ Hindi } & Maqbool (2004) & Vishal Bhardwaj & Othello \\
\cline { 2 - 4 } & Omkara (2006) & Vishal Bhardwaj & Hamlet. \\
\cline { 2 - 4 } & Haider (2014) & Debu sen & The comedy of Errors \\
\cline { 2 - 4 } & Do Dooni Chaar (1968) & Gulzar & The comedy of Errors \\
\cline { 2 - 4 } & Angoor (1982) & Sharat Katariya & A Midsummer Night's Dream \\
\cline { 2 - 3 } & 10 ml Love &
\end{tabular}

Maqbool, director Vishal Bharadwaj's adaptation of Shakespeare's Macbeth If Shakespeare's works are the epitome of English literature, then Vishal Bhardwaj's Maqbool is the epitome of adaptive cinema. Shakespeare's classic tale of selfishness and ambition is transplanted to Mumbai's criminal underworld in this adaptation of Macbeth from Indian writer-director Vishal Bhardwaj (Makdee). The story follows Maqbool (Macbeth: Irfan Khan), the righthand man of Abbaji (King Duncan: Pankaj Kapoor) - the most powerful and influential ganglord in Mumbai. Abbaji's mistress Nimmi (Lady Macbeth: Tabu) falls in love with Maqbool \& inspires him to kill Abbaji and take-over his empire. What they did not expect was the surfacing of guilt, and loyals to Abbaji.

\section{Angoor directed by Gulzar is inspired by Shakespeare's play COMEDY OF ERRORS. \\ Angoor is considered to be one of the best Hindi comedy movies of all time. Raj Tilak and his wife are on a trip with their twins sons whom they call Ashok. According to Mr. Tilak's they look same so their name should be same. One day Raj Tilak is on his way with his wife and kids, In the mid way Taj Tilak found another pair of identical twins whom he adopts and name Bahadur (Deven Verma). This time also both the twins named same 'Bahadur'. An unfortunate accident will soon divide this extended family with each parent having one child each. Forward a few years later Ashok (Sanjeev Kumar) is married to Sudha (Moshumi) and Bahadur (Deven Verma) is married to Prema (Aruna Irani). They and Sudha's sister Tanu (Deepti Naval) all stay together. Into their lives and that of all the city folk enter the other Ashok, a detective novel offender, and Bahadur, a bhang lover. Now there are two Ashok's and Bahadurs in the same city}

Omkara, director Vishal Bharadwaj's adaptation of Shakespeare's Othello

This tale finds Shakespeare's "Othello" transplanted to gritty modern India. Omkara (Othello/ Ajay Devgan) strong-arms the locals into following his boss, the politician Rajan Tiwari (Roderigo/Deepak Dobrial) Bhaisaab (Duke of Venice/Naseeruddin Shah)

Eventually, Omi enters politics himself and appoints one of his assistant, Kesu ( Cassio/ Vivek Oberoi), to fill his place. This entices the jealousy of Langda (lago/Saif Ali khan), and he hatches a revenge plot. Langda plants seeds of doubt in Omi's mind, concerning the faithfulness of Omi's new bride Dolly (Desdemona/Kareena Kapoor).The year 2007 marks the 385th anniversary of the first publication of Othello. The movie Omkara can be said to be on the global theme of suspicion kills. Some might think the director had liberally borrowed themes from Hindu epics - such as Ramayana (suspicion of the wife and listening to false counsel) and Mahabharata (power and the politics of power) - rather than Othello. However, for those who have not read Othello are bound to enjoy the movie more, as the ending will be a surprise to them.

\section{Om Shanti Om and Hamlet}

Hamlet is, at its essence, about avenging a loved one's death in the most melodramatic way

Possible. It therefore follows that when making a movie whose primary purpose is to mock

Bollywood's melodramatic tendencies, they would just decide to rewrite Hamlet.

But Hamlet doesn't lend itself well to song and dance sequences with happy endings where

everyone ends up happily in love - or even alive! How can we mock Bollywood without a love

Story and a happy ending? As Om Shanti Om reminds us: "Hamare filmon main...agar thik na ho to vo end nhi; picture abhi to see Shakespeare as simply one of the legacies of British colonialism in India. But his popularity in Hindi cinema is not just the culmination of Thomas Macaulay's Minute on Indian Education (1835), in which the colonial official infamously declared that "a single shelf of a good European library worth the whole native literature of India and Arabia". It also has a lot to do with profound resonances between Shakespeare's craft and Indian cultural forms that converge on one concept: masala. baaki hai..." (In our films... if it's not happy, then it's not the end).

The answer is: we reinvent it.

Instead of Hamlet taking revenge for his father's murder, we have Om taking revenge for the murder of his beloved Shanti. Throw in some back story (one thing I love about Bollywood is that very rarely is character development taken for granted), a bit of rebirth and more than a handful of clever references to ' 60 s Bollywood, and we have a film!

\section{Volume 6 Issue 12, December 2017}




\section{International Journal of Science and Research (IJSR) \\ ISSN (Online): 2319-7064}

Index Copernicus Value (2016): 79.57 | Impact Factor (2015): 6.391

\section{Dil Bole Hadippa! And The Twelfth Night}

Dil Bole Hadippa! is a pure Shakespearean comedy. The plot line of this movie is awesome, where a girl try to prove her caliber in men's world by pretending to be men. But eventually fall in love. Dil Bole Hadippa! does this through bubbly Punjabis with over-decorated trucks and excessive ethnic pride.

\section{Ishaqzaade and Romeo and Juliet}

The latest adaption of Romeo and Juliet is in the form of ISHAQZAADE, which has been set up against the cultural backdrop of Hindi hinterland where the guns still rule the roost and it is the ability to take it out and shoot it that determines the social standing of a person in the society.

This adaption of Romeo and Juliet, had its own twist and turns. Unlike it's predecessors, writers of Ishaqzaade keeping the basic plot same.

\section{Data Search}

Secondary data collection:

Collected from books journals, Research paper, thesis, Website, etc.

\section{Conclusion}

Although Shakespeare has not directly contributed to Indian Cinema. The 'Glocal' cinematizing of the plays of William Shakespeare in India has been an outstanding and ground breaking venture. Though India has diversification in society yet Shakespeare remembered for his character, who are very much alive today whatever be their race, religion, creed or language. Filmmaker of several generation inspired by his plays, it has been 450 years since he passed on but he has passed on more than just his works which offer best ingredients for cinema in any language that could belong to any culture, relationship and so on.

\section{References}

[1] http://www.thehindu.com/opinion/op-ed/shakespeare-inbollywood/article8510082.ece

[2] http://www.thecitizen.in/index.php/en/NewsDetail/index/ 9/8968/Shakespeare-The-Flavour-of-Indian-Cinema

[3] http://shodhganga.inflibnet.ac.in/bitstream/10603/16732/ 9/09_conclusion.pdf

[4] https://www.ijellh.com/cinematizing-shakespeare-studyshakespearean-presence-indian-cinema

[5] http://www.readfingers.com/cinematic-adaptations-ofshakespearean-tragedies-in-india-maqbool-omkarahaider/

[6] https://mediaindia.eu/cinema/six-works-by-shakespearethat-inspired-indian-cinema/ 